\title{
SELECTED OPHTHALMIC AND PHYSIOLOGIC PARAMETERS IN RABBITS (ORYCTOLAGUS CUNICULUS) SUBMITTED TO RETROBULBAR BLOCK WITH LIDOCAINE, MORPHINE OR KETAMINE
}

\author{
AVALIAÇÃO DE PARÂMETROS OFTÁLMICOS E FISIOLÓGICOS EM COELHOS \\ (ORYCTOLAGUS CUNICULUS) SUBMETIDOS A BLOQUEIO RETROBULBAR \\ COM LIDOCAÍNA, MORFINA OU CETAMINA
}

\author{
Débora Passos Hinojsa SCHÄFFER ${ }^{1}$; Camila Pinho Balthazar da SILVEIRA ${ }^{2}$; \\ Newton NUNES ${ }^{2}$, José Luis LAUS ${ }^{2}$; Nayone Lima Lantyer Cordeiro de ARAUJO' \\ Emanoel Ferreira MARTINS FILHO ${ }^{1}$; Arianne Pontes ORIÁ ${ }^{1}$ \\ 1. School of Veterinary Medicine and Zootechny, Federal University of Bahia - UFBA, Salvador, BA, Brazil; 2. School of Agricultural \\ and Veterinary Sciences at Jaboticabal, São Paulo State University - UNESP, Jaboticabal, SP, Brazil. arianneoria@ufba.br
}

\begin{abstract}
The aim of the present study was to evaluate selected ophthalmic and physiologic parameters in rabbits submitted to retrobulbar blockade with lidocaine, morphine or ketamine. Eighteen adult rabbits, seven males and eleven females, New Zealand White breed, weighing $3.9 \pm 0.7 \mathrm{~kg}$ were randomly assigned to perform the retrobulbar block according to the groups: LID ( $2 \%$ lidocaine without a vasoconstrictor $\left.-7 \mathrm{mg} \mathrm{kg}^{-1}\right)$; MOR (1\% morphine - $1 \mathrm{mg} \mathrm{kg}$ ) or KET $\left(10 \%\right.$ Ketamine $\left.-5 \mathrm{mg} \mathrm{kg}^{-1}\right)$. Ophthalmic and physiologic parameters were assessed, including lacrimal production using Schirmer tear test (STT), corneal touch threshold (CTT), pupillary diameter, intraocular pressure (IOP), pulse rate $(\mathrm{PR})$, respiratory rate $(\mathrm{RR})$, oxyhemoglobin saturation $\left(\mathrm{SpO}_{2}\right)$, rectal temperature $(\mathrm{RT})$ and systolic, mean and diastolic blood pressures (SAP, MAP and DAP) and were evaluated every 10 minutes for 70 minutes. All drugs used in the present study promoted central positioning of the eyeball for up to one minute later the retrobulbar administration in all cases. There was a significant increase of STT values in MOR and LID, when compared to baseline, while the CTT values had a significant decrease in all groups. KET kept the IOP values unaltered at the time points and there was a significant decrease of pupillary diameter in MOR. There was no significant change in PR, RR and $\mathrm{SpO}_{2}$; however, LID presented significantly lower values of SAP. MOR had increased values for RT when compared to the other two groups. The established parameters may help in ophthalmic procedures using retrobulbar nerve blocks.
\end{abstract}

KEYWORDS: Dissociative anesthetics. Eye. Lagomorphs. Local anesthesia. Opioids.

\section{INTRODUCTION}

Several anesthetic techniques can be established for ophthalmic surgeries. However, some particularities as akinesia, eyeball immobility, maintenance of normal intraocular pressure (IOP), absence of oculocardiac reflex and preservation of the greater pupil diameter possible should be considered when choosing the anesthetic method (AQIL, 2010; HAZRA et al., 2011).

Retrobulbar nerve block (RNB) provides analgesia, helps to reduce the occurrence of oculocardiac reflex and has the advantage of low cost to performance (HEMMERLING et al., 2000; MYRNA et al., 2010; SHILO-BENJAMINI et al., 2013). In small animals, it may be an alternative to systemic administration of neuromuscular blocking agents for ophthalmic surgery, with no interference on cardiovascular and respiratory functions (CARREGARO et al., 2006; OLIVA et al., 2010).

Different techniques for retrobulbar administration of local anesthetics and other drugs associations have been described in Veterinary
Medicine; but all of them present the solution deposition within the muscle cone as a characteristic in common (ACCOLA et al., 2006; MASSONE, 2011). Lidocaine is a local anesthetic routinely used in veterinary practice, and it is associated with fast action onset and short lasting effects (ACCOLA et al., 2006; AKSU et al., 2009; HAZRA et al., 2011). The retrobulbar application of lidocaine promoted satisfactory anesthetic action, with extraocular muscle relaxation, avoiding the use of neuromuscular blocking agents (RAMAKRISHNA 1995; JACOBI et al., 2000). In rabbits, a research obtained good results with lidocaine via retrobulbar space in patients under dissociative anesthesia, but with parameters influenced by the association of ketamine and xylazine (HAZRA et al., 2011).

Drugs like ketamine and morphine as well as the lidocaine, have the blockade of sodium channels as a characteristic (GILLY et al., 1985; BRAU et al., 1997; AKSU et al., 2009). However, there are few studies on peripheral use of these agents for analgesia or local anesthesia (KAPITZKE et al., 2005). These drugs are frequently used in 
parenteral analgesic associations (BONFIGLIO et al., 2006) and in regional blocks, as the epidural route (ACOSTA et al., 2005; O; SMITH, 2013). Therefore, the paucity of data on retrobulbar block using these drugs individually, in rabbits, motivated its use in the present investigation.

With the advance of the balanced anesthesia techniques, analgesic drugs must be studied in order to promote a residual pain control and increased post-operative comfort to the patient. Moreover, the knowledge of these drugs effects on ophthalmic and physiologic parameters are scarce (HONSHO et al., 2014; SILVA et al., 2015) and this is essential to ensure the eye health after ophthalmic surgeries. Thus, the aim of the present study was to evaluate selected ophthalmic and physiologic parameters in rabbits submitted to retrobulbar block with lidocaine, morphine or ketamine.

\section{MATERIAL AND METHODS}

\section{Ethical considerations}

The present study was approved by the Animal Care and Use Committee of Federal University of Bahia (no. 23/2012). In addition, all procedures were performed in accordance with the humane principles set forth in the Association for Research in Vision and Ophthalmology (ARVO) Statements for the Use of Animals in Ophthalmic and Vision Research.

\section{Animals}

Eighteen adult rabbits, seven males and eleven females, New Zealand White breed, weighing $3.9 \pm 0.7 \mathrm{~kg}$ were used. All animals were kept in the experimental sector of the Clinic and Surgery Department of the School of Agricultural and Veterinarian Sciences of Universidade Estadual Paulista (UNESP), Jaboticabal Campus. Rabbits were housed in individual cages of $80 \mathrm{~cm}$ x $50 \mathrm{~cm} \mathrm{x}$ $35 \mathrm{~cm}$ and supplied with commercial feed, fresh vegetables and water ad libitum.

A physical examination was performed in each animal, before the study. Rabbits with indication of systemic, periocular and ophthalmic disease were excluded. All ophthalmic and physiologic data were collected by the same investigators in three different stages, on consecutive moments, in the morning, in the same room and conducted on two days. Stages two and three were conducted on the same day, separated by execution of the retrobulbar block.

The animals were randomly distributed into three groups of six animals each. The rabbits were not fasted before the experiment, once the occurrence of emesis is rare during the anesthetic induction (FLECKNELL et al., 2007). Furthermore, feed withdrawal is not feasible in this species due to its coprophagic habit (LONGLEY, 2008).

\section{Stage one: Baseline of ophthalmic parameters}

Twenty-four hours before the anesthetic procedure, the animals were submitted to the selected ophthalmic diagnostic tests: Schirmer tear test (STT), corneal touch threshold (CTT), pupillary diameter and intraocular pressure (IOP). Lacrimal production was assessed using sterile STT strips (Ophthalmos, São Paulo/SP, Brazil) placed in the lower conjunctival fornix for 60 seconds and immediately measured in millimeters from the scale printed on the strip.

For evaluation of corneal sensitivity, a Cochet Bonnet esthesiometer (Luneau Ophthalmologie, Paris, France) was used, starting with a $60 \mathrm{~mm}$-long nylon filament. The central region of the cornea was touched perpendicularly until the filament bent slightly. The test was performed twice, with a minimum interval of 20 seconds between evaluations, and if the animal did not blink (negative response), the filament length was reduced gradually at $5 \mathrm{~mm}$ until obtaining a blink reflex.

The pupillary diameter was assessed in millimeters through a Castroviejo compass (Petrovich® - Surgery, São Paulo/SP, Brazil) positioned in front of the cornea. IOP was measured using an applanation tonometer (TonoPenVet, Reichert, USA) positioned perpendicularly to the cornea after instillation of one drop of sterile topical anesthetic (Anestalcon $\AA$, $0.5 \%$ proxymetacaine hydrochloride, Alcon, São Paulo/SP, Brazil). Three averaged measurements were performed in each eye. The SD value of $5 \%$ provided by the equipment in millimeters of mercury $(\mathrm{mmHg})$ was considered. The instillation of anesthetic eye drops was not repeated in the following measurements, to avoid changes in corneal sensitivity.

\section{Stage two: Baseline of physiologic parameters}

Rabbits were physically restrained and positioned on the table for measurement of the following parameters: Pulse rate (PR), respiratory rate $(\mathrm{RR})$, pulse oximeter oxygen saturation $\left(\mathrm{SpO}_{2}\right)$ and rectal temperature (RT).

Then, the animals were anesthetized using a sealed naso-oral mask connected to a Mapleson D breathing system. Anesthesia was induced with isoflurane (Isofluorano®, isoflurane, Biochimico, Rio de Janeiro/RJ, Brazil) at 5\% dial settings in an oxygen flow of $300 \mathrm{~mL} \mathrm{~kg}$ minute $^{-1}$, delivered 
from an anesthesia machine (OHMEDA, mod. Excel 210SE, Madison, EUA) with a thermocompensated and calibrated vaporizer (OHMEDA - mod. ISOTEC 5; Datex OhmedaMiami, EUA).

After anesthetic induction, the animals were maintained on $3.5 \%$ dial setting isoflurane according to second and third anesthetic plans of the third stage described by Guedel (presence of miosis and rotation of the globe). Cannulation of the central auricular artery was performed to measure systolic, mean and diastolic blood pressures (SAP, MAP and DAP).

The $\mathrm{SpO}_{2}$ was investigated through direct reading in oximetry, with the sensor positioned on the ear cartilage of the animals. The PR was obtained using the oximetry sensor positioned on the ear cartilage. The RR was measured using the capnometry sensor from the multiparameter monitor attached to the oro-nasal mask. The SAP, DAP and MAP were determined using the pressure transducer multiparameter monitor (Dixtal, Model Dx2010, Manaus/AM, Brazil) attached to the catheter positioned in the central ear artery. The arterial pressure transducer was positioned at heart level, with zero as reference value $(00 \mathrm{mmHg})$ and adjusted periodically according to atmospheric pressure. The RT was measured using a mercury thermometer positioned in the rectum for sixty seconds.

\section{Stage three: Retrobulbar block, ophthalmic and physiologic parameters}

For this stage, each group was treated with one of the following anesthetic drugs: LID group: 2\% lidocaine (Xylestesin ${ }^{\circledR}$, lidocaine hydrochloride, Cristália, São Paulo/SP, Brazil) without a vasoconstrictor (7 mg kg-1); MOR group: $1 \%$ morphine (Dimorf®, morphine sulfate, Cristália, São Paulo/SP, Brazil) $\left(1 \mathrm{mg} \mathrm{kg}^{-1}\right)$; KET group: $10 \%$ Ketamine (Dopalen ${ }^{\circledR}$, ketamine hydrochloride, CEVA, Paulínia/SP, Brazil) $\left(5 \mathrm{mg} \mathrm{kg}^{-1}\right)$.

In all of the groups, the drugs were diluted in saline solution $(\mathrm{NaCl} 0.9 \%)$ to a standard volume of $2 \mathrm{~mL}$ for each animal.

After blood pressure measurement, the animals were positioned in left lateral recumbence for the ocular antisepsis using polyvinylpyrrolidoneiodine solution diluted in $\mathrm{NaCl} 0.9 \%$ in the ratio 1:100. For the RNB, a $25 \mathrm{~mm}$ x $0.7 \mathrm{~mm} 22$ gauge hypodermic needle (Becton Dickinson, Brazil Curitiba/PR, Brazil) was inserted through the medial canthus, with the bevel facing the eyeball, parallel to the orbit, and then angled at $45^{\circ}$ and directed to the intraconal space (Myrna et al., 2010). The syringe plunger was pulled before injection to confirm correct placement of the needle and prevent accidental intravascular administration.

Immediately after the RNB, the delivering of volatile anesthetic was turned off and the animals were maintained only in $100 \%$ oxygen until anesthetic recovery, which ranged from $2-6$ minutes.

Ten minutes after the blockade (T1), with the animals only under effect of local anesthesia, CTT, pupil diameter, IOP, PR, RR, $\mathrm{SpO}_{2}, \mathrm{SAP}$, MAP and DAP and RT were assessed every 10 minutes for 70 minutes (T1-T7), except for STT values, which were measured only at $\mathrm{T} 0$ and $\mathrm{T} 7$. Meloxicam $\left(0.2 \mathrm{mg} \mathrm{kg}^{-1}\right)$ was administered intramuscularly in all animals at the end of the study and a reevaluation was performed, by the same investigator, after 24 hours for ophthalmic abnormalities or adverse reactions.

\section{Statistical analysis}

The Shapiro-Wilk test was used to assess the normality of the variables STT, CTT, IOP, PR, RR, SpO2, RT, SAP, DAP and MAP within the same group at sequential time points. The Friedman test was used to evaluate differences among time points in the same group, excepted by STT which was evaluated by Wilcoxon matched-pairs test. To test for differences between groups at the same time point, the Kruskal-Wallis test and Dunn's multiple comparisons test were performed. The Spearman test was used to test the correlation between MAP and IOP.

\section{RESULTS}

All drugs used in the present study promoted central positioning of the eyeball for up to one minute later the retrobulbar administration in all cases, while the contralateral eye remained rotated. Statistical results of CTT and pupillary diameter are described in Figure 1, and descriptive IOP results are described in Figure 2. Median \pm semiinterquartile range STT (measured in T0 and T7) was $8.5 \pm 2.38 \mathrm{~mm} / \mathrm{min}$ and $11.5 \pm 2.5 \mathrm{~mm} / \mathrm{min}, 8.5$ $\pm 1.38 \mathrm{~mm} / \mathrm{min}$ and $15.0 \pm 3.88 \mathrm{~mm} / \mathrm{min}$, and $8.0 \pm$ $0.5 \mathrm{~mm} / \mathrm{min}$ and $11.0 \pm 1.63 \mathrm{~mm} / \mathrm{min}$, for LID, MOR and KET, respectively. There was a significant increase of STT values in MOR and LID at T7 ( $p<0.031)$, when compared to baseline (T0). There was a significant decrease in CTT values in all groups, at $\mathrm{T} 1$ and $\mathrm{T} 2$, when compared to $\mathrm{T} 0(\mathrm{p}<$ 0.02). Besides, LID maintained a significant decrease at T3 and T4 $(\mathrm{p}<0.0001)$. There was a significant difference between LID and MOR at T1 
- T4 $(\mathrm{p}<0.05)$, and between LID and KET at T5 T7 $(\mathrm{p}<0.0171)$. There was a significant increase of IOP values in MOR, at T1 $(\mathrm{p}=0.010)$ and $\mathrm{LID}$, at $\mathrm{T} 1$ - T4 $(\mathrm{p}=0.002)$ compared to T0. However, KET kept the IOP values unaltered at the same times $(p=0.523)$. There was a significant decrease of pupillary diameter in MOR ( $\mathrm{p}=0.0006)$, at $\mathrm{T} 1$ and $\mathrm{T} 2$, when compared to T0. When comparing groups, MOR presented values of pupillary diameter significantly lower than LID, at T1 - T7 (p < 0.0256).

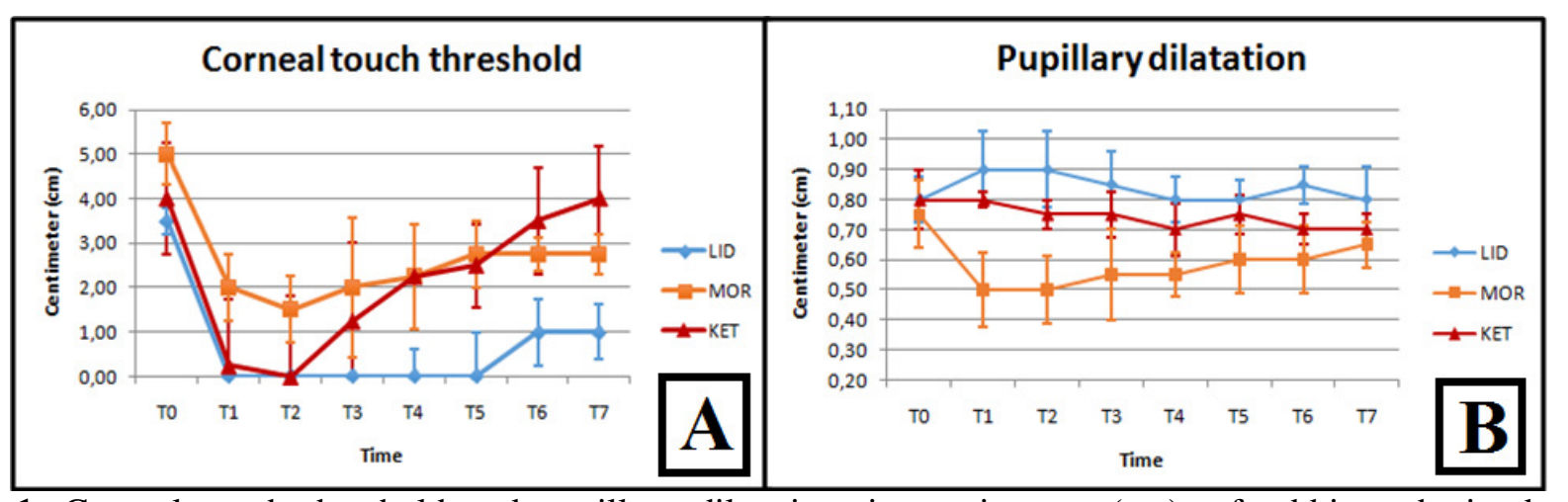

Figure 1. Corneal touch threshold and pupillary dilatation, in centimeters (cm), of rabbits submitted to retrobulbar blockade using lidocaine, morphine or ketamine. Median \pm semi-interquartile range (SIQR). LID, Lidocaine group; MOR, Morphine group; KET, Ketamine group.

There was no significant difference in PR, $\mathrm{RR}$ and $\mathrm{SpO}_{2}$ among groups and studied times, in comparison to baseline ( $\mathrm{p}>0.05)$. Descriptive statistical results of SAP, DAP and MAP are described in Figure 2 and 3. There was no significant difference of SAP in MOR for any evaluated time, when compared to T0. However, LID presented a significant decrease in $\mathrm{T} 2$ to $\mathrm{T} 4$, compared to T0 $(\mathrm{p}=0.0117)$ and KET in $\mathrm{T} 1$ and $\mathrm{T} 2$ ( $p=0.0047)$. There was no difference among groups in T1, T3 and T7, but LID showed significant lower values in $\mathrm{T} 2, \mathrm{~T} 4, \mathrm{~T} 5$ and $\mathrm{T} 6$, when compared to MOR $(\mathrm{p}<0.031)$. DAP results showed no significant difference between LID and KET from $\mathrm{T} 1$ to T7, but MOR and KET differed only in T2 (p $=0.0147)$. There was no significant difference in MAP among groups and studied times, in comparison to baseline $(\mathrm{p}>0.05)$. The Spearman test showed no correlation between MAP and IOP in any of the groups at any of the time points ( $p>0.08$, absolute $\rho<-0.25$ ).

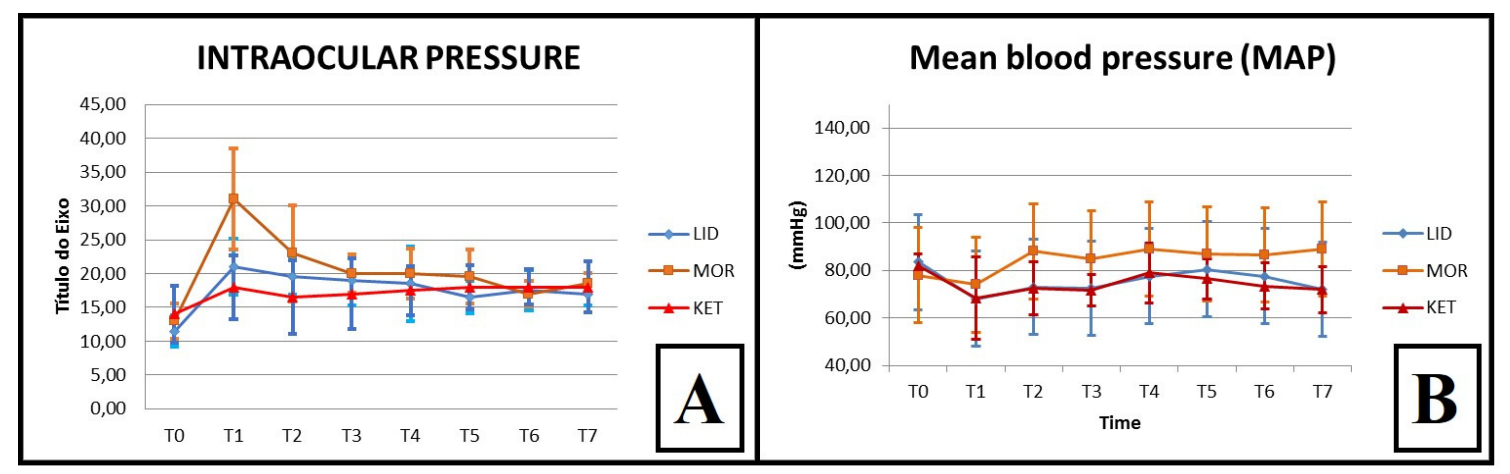

Figure 2. Intraocular pressure (A) and mean arterial pressure (B), in $\mathrm{mmHg}$, of rabbits submitted to retrobulbar blockade using lidocaine, morphine or ketamine. Median \pm semi-interquartile range (S-IQR). LID, Lidocaine group; MOR, Morphine group; KET, Ketamine group. 


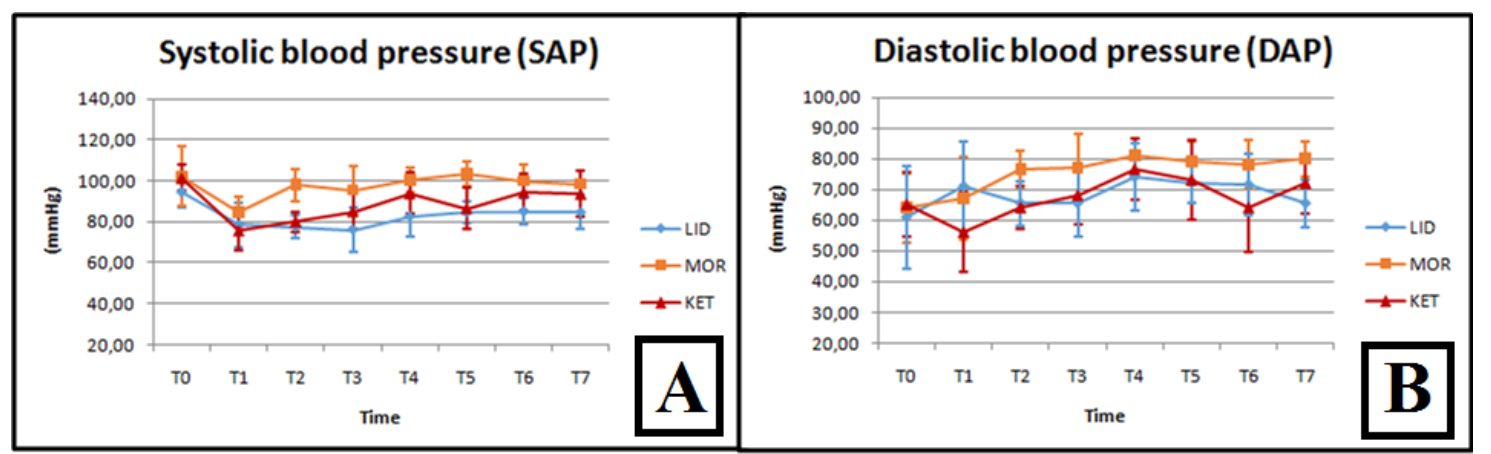

Figure 3. Systolic (A) and diastolic (B) blood pressure, in $\mathrm{mmHg}$, of rabbits submitted to retrobulbar blockade using lidocaine, morphine or ketamine. Median \pm semi-interquartile range (S-IQR). LID, Lidocaine group; MOR, Morphine group; KET, Ketamine group.

There was no significant difference for rectal temperature in all groups at T1-T7 compared to T0. However, when comparing groups, MOR had increased values $(\mathrm{p}<0.038)$ at $\mathrm{T} 2(39.6 \pm 0.66), \mathrm{T} 4$ $(39.9 \pm 0.88)$, T5 $(39.8 \pm 0.47)$, T6 $(40.0 \pm 0.56)$ and T7 (40.0 \pm 0.58$)$, when compared to KET.

Post anesthetic complications, like chemosis, lacrimation and conjunctival hyperemia, were observed in all of the groups. However, they were reversible up to 24 hours later, when the complete ophthalmic exam was normal. Ocular hemorrhage with nasal drainage was observed where the needle was inserted, immediately after blockade.

\section{DISCUSSION}

The use of ketamine has been extensively investigated in epidural route with favorable results (LAVOR et al., 2004; CARREGARO et al., 2010). Nevertheless, some studies about peripheral nerve blocks have described variable results, demonstrating questionable effects in different species (BAILARD et al., 2014). In the present study, rabbits received this drug in retrobulbar route and good physiologic and ophthalmic stability was observed, characterized by IOP and papillary dilatation maintenance.

The central positioning of the globe was observed in every group. Similar results were described in the literature, with use of lidocaine as promoter of eyeball centralization after desensitization, and therefore extraocular muscles relaxation (ACCOLA et al., 2006; AKSU et al., 2009). Ketamine also uses the same mechanism of action, due to its local anesthetic properties (ELHAMID; OTHMAN, 2011) while morphine is traditionally used in association with local anesthetics to enhance their effect (MERCANOĞLU et al., 2013).
In this study, we observed the central eye positioning with the isolated use of morphine via retrobulbar injection. However, the mechanism of action that achieves this effect has not been elucidated yet. The lack of a control group is a limitation, since having a control group without action of analgesic/anesthetic could help to identify whether the centralization of the globe was a result of these drug's action or the administered volume.

There was no increase of tear production in LID and KET, as determined by STT. These results were in accordance with the reference values for rabbits $(7.9 \pm 3.6 \mathrm{~mm} / \mathrm{min} ; 12.0 \pm 2.5 \mathrm{~mm} / \mathrm{min}$ and $7.27 \pm 2.51 \mathrm{~mm} / \mathrm{min}$ ) described by Koç et al. (2005), Williams (2007) and Oriá et al. (2014). Similar findings were described by Accola et al. (2006), using lidocaine in dogs. However, Honsho et al. (2014) described a significant decrease of tear production in dogs after the blockade with lidocaine, requiring lubrication with artificial tears. Results for tear production in MOR exceeded the reference values reported for this species (KOÇ et al., 2005; WILLIANS, 2007; ORIÁ et al., 2014). However, Sano et al. (2010) did not found significant difference of tear production with morphine $(0.2$ $\mathrm{mg} / \mathrm{kg}$ ) for peribulbar block in dogs. This result may be related to the increase in IOP produced by morphine or to a possible discomfort caused by its use in this route.

A decrease in CTT values was observed in all of the groups, but only LID showed complete corneal insensitivity for 30 minutes (T1-T5), with esthesiometry values between zero and $0.5 \mathrm{~cm}$ (SHARROW-REABE; TOWNSEND, 2012; THOMSON et al., 2013). In addition, a similar effect was observed using lidocaine for peribulbar and retrobulbar block in humans (RIPART et al., 2001) and in dogs (KLAUMANN et al., 2008; HONSHO et al., 2014). The reduction in corneal sensitivity observed in KET and MOR groups for nearly twenty minutes was also reported by 
Thomson et al. (2013), after instillation of morphine on the ocular surface. Similar results were described by Sano et al. (2010), who reported a significant decrease in CTT values after the use of morphine $(0.2 \mathrm{mg} / \mathrm{kg})$ for peribulbar block in dogs. Perhaps, the reduction of CTT in KET may be resulted by the antinociceptive and analgesics effects of ketamine as reported in different species (SEGURA et al., 1998; DUQUE et al., 2004) after epidural administration. Other authors observed similar results related to the peripheral and antinociceptive action of ketamine and morphine used alone or in combination (LILLES $\varnothing$ et al., 2000; KAPITZKE et al., 2005). However, peripheral morphine effects were not observed in the retrobulbar space after intraocular surgery in humans (HEMMERLING et al., 2000).

LID and KET were efficient to maintain a pupillary dilatation as cited by Aksu et al. (2009) after lidocaine administration on retrobulbar space. It is an important parameter for intraocular surgeries, which requires a complete mydriasis (CARARETO et al., 2007). MOR group showed a significant reduction in pupil diameter, ranging from $0.75 \mathrm{~cm}$ to $0.50 \mathrm{~cm}$, similar to described by DortchCarnes and Russel (2006), who obtained a reduction in pupil diameter with the topical instillation of 100 $\mu \mathrm{g}$ morphine on the cornea and also reported by Bonfiglio et al. (2006) after systemic morphine administration. The failure in promote mydriasis is an unfavorable condition for intraocular surgeries, by reducing the surgical field, increasing the risk of bleeding and damage to the iris, or cause rupture in the posterior chamber (CORBETT; RICHARDS, 1994; AQIL, 2010).

IOP demonstrated significant increase in LID and MOR immediately after the blockade, exceeding the reference values for rabbits of $12.89 \pm$ $2.80 \mathrm{mmHg}$ described by Oriá et al. (2014). These results were different from reported by Honsho et al. (2014), who did not obtained IOP elevation after administration of $2 \mathrm{ml}$ lidocaine into the retrobulbar space of dogs, and Dortch-Carnes and Russell (2006), who described an ocular hypotension of morphine after corneal instillation. For Accola et al. (2006), a transient increase of IOP occurs after retrobulbar block, probably due to an elevation in the intraorbital pressure after injection of great amount of anesthetics. However, in the present study, different from other groups, the increase in IOP was not observed in KET, after blockade with the same volume administered. This result corroborates with some authors that suggests there is no relationship between the use of ketamine and the elevation of IOP. The known pharmacodynamics of ketamine are such that associated change of IOP would be unlikely using this route (DRAYNA et al.; 2012). Different results were reported after systemic use of ketamine, promoting an increase of IOP after xylazine association in dogs (LIN, 2007), or not promoting IOP elevation with the same association with xylazine systemically in rabbits (HAZRA et al., 2011). The injection of two milliliters was similarly reported by Accola et al. (2006) in dogs without any complications after this volume administration, but was superior to results described by Drayna et al. (2012) and Silva et al. (2015), in rabbits.

There were no significant changes observed in $\mathrm{PR}, \mathrm{RR}$ and $\mathrm{SpO} 2$ in rabbits, remaining within the physiological ranges for this species (HEDENQVIST, 2008). The retrobulbar block can prevent heart rate alterations, mainly when related to a decrease associated with initiation of the oculocardiac reflex (OEL et al., 2014).

Errando et al. (1999) reported an increase of SAP, DAP and MAP due to sympathetic stimulation, after parenteral ketamine administration. Following the retrobulbar blockade, a significant reduction in SAP was observed in KET. This effect probably occur due to a ketamine depressor phase, observed by some authors, which occurs within the first few minutes, and it is related to a direct vascular smooth muscles relaxation (ALTURA et al., 1980).

Several adverse effects and complications have been described in the literature, arising from retrobulbar block, including conjunctival hemorrhage, chemosis, corneal ulceration (KLAUMANN, 2007; AQIL, 2010; HONSHO et al., 2014) and cardiorespiratory arrest (RAMAKRISHNA, 1995). The chemosis and ocular hemorrhage observed in this study were also described by Honsho et al. (2014) and Klaumann (2007) after retrobulbar block in dogs. Serious complications reported by Ripart et al. (2001), such as corneal injury or injuries to the optic nerve were not observed. The intercurrences observed in this study may be associated to the puncture site for the blockade in the medial corner of the eye, because the leporine species presents the most developed retrobulbar plexus when compared to the other species.

\section{CONCLUSION}

The retrobulbar block using lidocaine, morphine or ketamine was sufficient in promoting the reduction of the corneal sensitivity and maintaining the physiologic parameters, without 
decrease of tear production. Ketamine remained the intraocular pressure stable. However, the isolated use of morphine reduced the pupillary diameter and increased the intraocular pressure, as well as the lidocaine. The retrobulbar block is a method indicated to ophthalmic surgeries, in order to promote a balanced anesthesia, which results in improved post-operative comfort to the patient. Therefore, the determination of ophthalmic and physiologic parameters is of great importance for substantiating the choice of the more adequate drug for the loco-regional blockade and thus, further trials are needed to show if the combination of these drugs enabling its use as adjuvants in the retrobulbar anesthesia.

\section{ACKNOWLEDGEMENTS}

The authors would like to thank to Coordination for the Improvement of Higher Education Personnel (CAPES) for the financial support, the Veterinary Ophthalmology sector and the Emergency and Anesthesia sector of School of Agricultural and Veterinary Sciences at Jaboticabal, São Paulo State University, UNESP for their generous hospitality in the use of their facilities and to Monica Horr and Ana Paula Gering for their voluntary assistance.

RESUMO: Objetivou-se com o presente estudo estabelecer parâmetros oftálmicos e hemodinâmicos em coelhos submetidos ao bloqueio retrobulbar com lidocaína, morfina ou cetamina. Dezoito coelhos da raça Nova Zelândia, adultos, sete machos e onze fêmeas, com peso de 3,9 $\pm 0,7 \mathrm{~kg}$ foram aleatoriamente distribuídos para realização de bloqueio retrobulbar de acordo com os seguintes grupos: LID (lidocaína $2 \%$ sem vasoconstrictor - $7 \mathrm{mg} / \mathrm{kg}$ ); MOR (morfina $1 \%$ - 1 $\mathrm{mg} / \mathrm{kg}$ ) ou KET (cetamina $10 \%-5 \mathrm{mg} / \mathrm{kg}$ ). Os seguintes parâmetros oftálmicos e hemodinâmicos foram avaliados: produção lacrimal através do teste lacrimal de Schirmer (TLS), limiar de sensibilidade corneana ao toque, diâmetro pupilar, pressão intraocular (PIO), frequência de pulso (FP) e respiratória (FR), saturação da oxihemoglobina $\left(\mathrm{SpO}_{2}\right)$, temperatura retal (TR) e pressão arterial sistólica, diastólica e média (PAS, PAD e PAM). Todos os fármacos utilizados no presente estudo promoveram centralização do bulbo do olho em até um minuto após a sua administração retrobulbar em todos os casos. Houve um aumento significativo do TLS no grupo MOR e LID, quando comparados aos valores basais, enquanto o limiar de sensibilidade corneana reduziu significativamente em todos os grupos. O grupo KET manteve os valores da PIO inalterados em todos os tempos e houve uma redução significativa do diâmetro pupilar no grupo MOR. Não houve alteração significativa dos valores de FP, FR e $\mathrm{SpO}_{2}$. No entanto, o grupo LID apresentou valores significativamente menores de PAS. O grupo MOR apresentou maiores valores de TR quando comparado aos demais grupos. Os parâmetros estabelecidos no presente estudo podem servir como base para a realização de procedimentos oftálmicos que requerem o uso de bloqueio retrobulbar.

PALAVRAS-CHAVE: Anestesia dissociativa. Anestesia local. Lagomorfos. Olho. Opióides.

\section{REFERENCES}

ACCOLA, P. J.; BENTLEY, E.; SMITH, L. J.; FORREST, L. J.; BAUMEL, C. A.; MURPHY, C. J. Development of a retrobulbar injection technique for ocular surgery and analgesia in dogs. J. Am. Vet. Med. Assoc., v. 229, n. 2, 2006, p. 220-225. https://doi.org/10.2460/javma.229.2.220

ACOSTA, A. D.; GOMAR, C.; CORREA-NATALINI, C.; BOPP, S.; POLYDORO, A.; SALA-BLANCH, X. Analgesic effects of epidurally administered levogyral ketamine alone or in combination with morphine on intraoperative and postoperative pain in dogs undergoing ovariohysterectomy. Am. J. Vet. Res., v. 66, n. 1, 2005 , p. 54 - 61. https://doi.org/10.2460/ajvr.2005.66.54

AKSU, R.; BICER, C.; OZKIRIS, A.; AKIN, A.; BAYRAM, A.; BOYACI, A. Comparison of 0.5\% levobupivacaine, $0.5 \%$ bupivacaine, and $2 \%$ lidocaine for retrobulbar anesthesia in vitreoretinal surgery. Eur. J. ophthalmol., v. 19, n. 2, 2009, p. 280-284.

ALTURA, B. M.; ALTURA, B. T.; CARELLA, A. Effects of ketamine on vascular smooth muscle function. Br. J. Pharmac., v. 70, 1980, p. 257 - 267. https://doi.org/10.1111/j.1476-5381.1980.tb07931.x 
AQIL, M. Local anesthesia for the ophthalmic surgery. Select the best technique for your patient. Saudi Med. J., v. 6, 2010, p. $605-614$.

BAILARD, N. S.; ORTIZ, J.; FLORES, R. A. Additives to local anesthetics for peripheral nerve blocks: Evidence, limitations, and recommendations. Am J Health-Syst Pharm, v.71, Mar 1, 2014. https://doi.org/10.2146/ajhp130336

BONFIGLIO, V.; BUCOLO, C.; CAMILLIERI, G.; DRAGO, F. Possible involvement of nitric oxide in morphine-induced miosis and reduction of intraocular pressure in rabbits. Eur. J. Pharmacol., v. 534, 2006, p. 227 - 232. https://doi.org/10.1016/j.ejphar.2006.01.045

BRAU, M. E.; SANDER, F.; VOGEL, W. G.; HEMPELMANN, G. Blocking mechanisms of ketamine and its enantiomers in enzymatically demyelinated peripheral nerve as revealed by single-channel experiments.

Anesthesiology, v. 86, n. 2, 1997, p. 394-404. https://doi.org/10.1097/00000542-199702000-00014

CARARETO, R.; NUNES, N.; SOUSA, M. G.; FERRO, P. C.; GUERRERO, P. N. H; NISHIMORI, C. T.; PAULA, D. P.; CONCEIÇÃO, E. D. V. Anestesia para Cirurgias Oftálmicas em Canídeos. Rev. Port. Ciên. Vet. v. 102, 2007, p. $35-42$.

CARREGARO, A. B.; GERARDI, P. M.; MUJALLI, M. C. L. C.; MARTINS, F. S. Blocking of ocular bulb extrinsic musculature by atracurium in inhalant anesthetized dogs under spontaneous breathing. Arq. Bras. Med. Vet. Zootec., v. 58, n. 6, 2006, p. 1057 - 1063. https://doi.org/10.1590/S0102-09352006000600013

CARREGARO, A. B.; FREITAS, G. C.; MARQUES, J. S.; TREIN, T. A.; POHL, V. H.; SALBEGO, F. Z.; RAISER, A. G. Cardiorespiratory and analgesic effects of ketamine via epidural route, intravenous continuous infusion or association of both, in dogs submitted to femoral osteosynthesis. Cienc. Rur., p. 1 - 7, 2010. Disponível em: <http://www.scielo.br/pdf/cr/2010nahead/a662cr2932.pdf> Acesso em: 24 jan. 2016.

CORBETT, M. C.; RICHARDS, A. B. Intraocular adrenaline maintains mydriasis during cataract surgery. Br. J. Ophthalmol. v. 78, 1994, p. 96 - 98. https://doi.org/10.1136/bjo.78.2.95

DORTCH-CARNES, J.; RUSSELL, K. R. Morphine-induced reduction of intraocular pressure and pupil diameter: role of nitric oxide. Pharmacology, v. 77, n. 1, 2006, p. 17 - 24. https://doi.org/10.1159/000091993

DRAYNA, P. C.; ESTRADA, C.; WANG, W.; SAVILLE, B. R.; ARNOLD, D. H. Ketamine sedation is not associated with clinically meaningful elevation of intraocular pressure. Am. J. Emerg. Med., v. 30, n. 7, 2012, p. 1215 - 1218. https://doi.org/10.1016/j.ajem.2011.06.001

DUQUE, J. C.; VALADÃO, C. A. A.; FARIAS, A.; ALMEIDA, R. M.; OLESKOVICZ, N. Pre-emptive epidural Ketamine or S(+)-Ketamine in post-incisional pain in dogs: a comparative study. Vet. Surg. v. 33, 2004, p.361 - 367. Disponível em: <http://www3.interscience.wiley.com/cgi-

bin/fulltext/118771331/PDFSTART>. Acesso em: 13 feb. 2016. doi:10.1111/j.1532-950X.2004.04052.x. https://doi.org/10.1111/j.1532-950X.2004.04052.x

EL-HAMID, A. M. A.; OTHMAN, M. S. K. The effect of addition of local or intravenous ketorolac and morphine as an adjuvant to local anesthetic in popliteal nerve block. A comparative study with epidural anesthesia for foot or ankle surgery in diabetic patient. Ain Shams J. Anesth., v. 4, n. 2, 2011, p. 49 - 56.

ERRANDO, C. L.; SIFRE, C.; MOLINER, S. Y.; VALÁ, J. C.; GIMENO, O.; MÍNGUEZ, A.; BOILS, P. Subarachnoid ketamine in swine pathological findings after repeated doses: acute toxicity study. Reg. Anesth. Pain Med., v. 24, n. 2, 1999, p. 146 - 152. https://doi.org/10.1016/S1098-7339(99)90076-7 https://doi.org/10.1097/00115550-199924020-00009 
FLECKNELL, P. A.; RICHARDSON, C. A.; POPOVIC, A. Laboratory animals. In: TRANQUILLI, W. J.; THURMON, J. C.; GRIMM, K. A. Lumb \& Jones' veterinary anesthesia and analgesia. 4. ed. Oxford: Blackwell Publishing, cap.30, 2007, p.765 - 78.

GILLY, H.; KRAMER, R.; ZAHOROVSKI, I. Local anesthetic effects of morphine and naloxone. Der Anaesthesist, v. 34, n. 11, 1985, p. 619-626.

HAZRA, S.; PALUI, H.; BISWAS, B.; KONAR, A. Anesthesia for Intraocular Surgery in Rabbits. Scand. J. Lab. Anim. Sci., v. 38, n. 2, 2011, p. $81-87$.

HEDENQVIST, P. Anaesthesia and analgesia for surgery in rabbits and rats: A comparison of the effects of different compounds. 2008. $57 \mathrm{f}$. Thesis (Doctoral of Physiology and Pharmacology), Karolinska Institutet, Stokholmo, 2008.

HEMMERLING, T. M.; BUDDE, W. M.; KOPPERT, W. JONAS, J. B. Retrobulbar Versus Systemic Application of Morphine During Titratable Regional Anesthesia via Retrobulbar Catheter in Intraocular Surgery. Anesth. Analg., v. 91, 2000, p. 585-588. https://doi.org/10.1097/00000539-200009000-00016 https://doi.org/10.1213/00000539-200009000-00016

HONSHO, C. S.; FRANCO, L. G.; CEREJO, S. A.; SEGATO, M. B.; FERREIRA, M. A.; BOLZAN, A. A.; DUQUE, C. T. E.; LAUS, J. L. Ocular effects of retrobulbar block with different local anesthetics in healthy dogs. Semina: Ciências Agrárias, Londrina, v. 35, n. 5, 2014, p. 2577 - 2590. https://doi.org/10.5433/1679$0359.2014 v 35 n 5 p 2577$

JACOBI, P. C.; DIETLEIN, T. S.; JACOBI, F. K. A. Comparative study of topical vs retrobulbar anesthesia in complicated cataract surgery. Arch. Ophthalmol., v. 118, 2000, p. 1037-1043.

https://doi.org/10.1001/archopht.118.8.1037

KAPITZKE, D.; VETTER, I.; CABOT, P. J. Endogenous opioid analgesia in peripheral tissues and the clinical implications for pain control. Ther. Clin. Risk Manag., v.1, n. 4, 2005, p. 279- 297.

KLAUMANN, P. R.; WOUK, A. F. P. F.; MONTIANI-FERREIRA, F.; VILANI, R. G. C. Comparative ropivacaine and lidocaine study concerning canine peribulbar block. MEDVEP: rev. cient. med. vet., Peq. anim. anim. estim; v. 6, n. 19, 2008, p. $268-277$.

KOÇ, Y.; ALKAN, F.; TEPELI, C. Schirmer tear test in different rabbits breeds. Hayvancilik Arastirma Dergisi, v. 15, 2005, p. $1-5$.

LAVOR, M. S. L.; POMPERMAYER, L. G.; SOUSA, A. P.; DUARTE, T. S. Comparative study of the effects of xylazine, butorphanol, ketamine and lidocaine by epidural in dogs. Ars Veterinária, v. 20, n. 2, 2004, p. 195 -202 .

LILLESØ, J.; HAMMER, N. A.; PEDERSEN, J. L.; KEHLET, H. Effect of peripheral morphine in a human model of acute inflammatory pain. Br. J. Anaesth., v. 85, n. 2, 2000, p. 228 - 232.

https://doi.org/10.1093/bja/85.2.228

LIN, H. Dissociative anesthetics. In: TRANQUILLI, W. J.; THURMON, J. C.; GRIMM, K. A. Lumb \& Jones' veterinary anesthesia and analgesia. 4. ed. Oxford: Blackwell Publishing, 2007, cap 12.

LONGLEY, L. A. Rodent anaesthesia. Anaesthesia of exotic pets. Elsevier, Edinburgh (Scotland), 2008, p. 59 - 84. https://doi.org/10.1016/B978-0-7020-2888-5.50005-8

MASSONE, F. Anestesiologia veterinária: farmacologia e técnicas: texto e atlas colorido. 6 ed. Rio de Janeiro: Guanabara Koogan, 2011. 428p. 
MERCANOĞLU, E.; ALANOĞLU, Z.; EKMEKCI, P.; DEMIRALP, S.; ALKIS, N. Comparison of intravenous morphine, epidural morphine with/without bupivacaine or ropivacaine in postthoracotomy pain management with patient controlled analgesia technique. Rev. Bras. Anestesiol., v. 63, n. 2, 2013, p. 213 219. https://doi.org/10.1590/S0034-70942013000200010 ;https://doi.org/10.1016/S0034-7094(13)70218-6

MYRNA, K. E.; BENTLEY, E.; SMITH, L. J. Effectiveness of injection of local anesthetic into the retrobulbar space for postoperative analgesia following eye enucleation in dogs. J. Am. Vet. Med. Assoc.,v. 237, n. 2, 2010, p. 174-177. https://doi.org/10.2460/javma.237.2.174

O, O.; SMITH, L. J. A. Comparison of epidural analgesia provided by bupivacaine alone, bupivacaine + morphine, or bupivacaine + dexmedetomidine for pelvic orthopedic surgery in dogs. Vet. Anaesth. Analg., v. 40, n. 5, 2013, p. 527 - 536. https://doi.org/10.1111/vaa.12050

OEL, C.; GERHARDS, H.; GEHLEN, H. Effect of retrobulbar nerve block on heart rate variability during enucleation in horses under general anesthesia. Vet Ophthalmol, v. 17, n. 3, 2014, p. $170-174$. https://doi.org/10.1111/vop.12061

OLIVA, V. N. L. S.; ANDRADE, A. L.; BEVIlACQUA, L.; MATSUBARA, L. M.; PERRI, S. H. V. Peribulbar anesthesia with ropivacaine as an alternative to neuromuscular blocking agents for cataract surgery in dogs. Arq. Bras. Med. Vet. Zootec., v. 62, n. 3, 2010, p. 586 - 595. https://doi.org/10.1590/S010209352010000300013

ORIÁ, A. P.; GOMES JÚNIOR, D. C.; ARRAES, E. A.; ESTRELA-LIMA, A.; PINNA, M. H.; MENESES, I. D. S.; MARTINS FILHO, E. F. Tear production, intraocular pressure and conjunctival microbiota, cytology and histology of New Zeland rabbits (Oryctolagus cuniculus). Pesq. Vet. Bras., v. 34, n. 10, 2014, p. 1024 1028. https://doi.org/10.1590/S0100-736X2014001000016

PLOOG, C. L.; SWINGER, R. L.; SPADE, J.; QUANDT, K. M.; MITCHELL, M. A. Use of lidocainebupivacaine-infused absorbable gelatin hemostatic sponges versus lidocaine-bupivacaine retrobulbar injections for postoperative analgesia following eye enucleation in dogs. J. Am. Vet. Med. Assoc., v. 244, n. 1, 2014, p. 57-62. https://doi.org/10.2460/javma.244.1.57

RAMAKRISHNA, O. Apnea following retrobulbar block in cattle. India Vet. J., v. 72, 1995., p. 97-98.

RIPART, J.; LEFRANT, J. Y.; DE LA COUSSAYE, J. E.; PRAT-PRADAL, D.; VIVIEN, B.; ELEDJAM, J. J. Peribulbar versus retrobulbar anesthesia for ophthalmic surgery: an anatomical comparison of extraconal and intraconal injections. Anesthesiology, v. 94, 2001, p. 56 - 62. https://doi.org/10.1097/00000542-20010100000013

SANO, D. H. Avaliação clínica da utilização de morfina por via peribulbar em cães. In: Livro de Resumos do $18^{\circ}$ Evento de Iniciação Científica, 2010, Anais... Curitiba, Paraná, 2010, p. 458.

SEGURA, I. A. G.; ROSSI, R.; SANTOS, M.; SAN-ROMAN, J. L.; TENDILLO, F. J. Epidural injection of ketamine for perineal analgesia in the horse. Vet. Surg., v. 27, 1998, p. $384-391$.

https://doi.org/10.1111/j.1532-950X.1998.tb00145.x

SHARROW-REABE, K. L.; TOWNSEND, W. M. Effects of action of proparacaine and tetracaine topical ophthalmic formulations on corneal sensitivity in horses. J. Am. Vet. Med. Assoc., v. 15, n. 12, 2012, p. 1645 - 1649. https://doi.org/10.2460/javma.241.12.1645

SHILO-BENJAMINI, Y.; PASCOE, P. J.; MAGGS, D. J.; KASS, P. H.; WISNER, E. R. Retrobulbar and peribulbar regional techniques in cats: a preliminary study in cadavers. Vet. Anaesth. Analg., v. 40, 2013, p. 623-631. https://doi.org/10.1111/vaa.12060 
SILVA, R. M. M.; DÓREA NETO, F. A.; BARBOSA, V. F.; NUNES, N.; MARTINS FILHO, E. F.; ORIÁ, A. P. Intraocular pressure, mean arterial blood pressure and pupillary diameter in rabbits (Oryctolagus cuniculus) subjected to retrobulbar block with different anesthetic protocols. Cienc. Anim. Bras., v. 16, n. 4, 2015, p 630 638. https://doi.org/10.1590/1089-6891v16i428316

THOMSON, S. M.; OLIVER, J. A.; GOULD, D. J.; MENDL, M.; LEECE, E. A. Preliminary investigations into the analgesic effects of topical ocular 1\% morphine solution in dogs and cats. Vet. Anaesth. Analg., v. 40, 2013, p. 632 - 640. https://doi.org/10.1111/vaa.12069

WILLIAMS, D. Rabbit and rodent ophthalmology. Ophthalmol. EJCAP, v. 17, n. 3, 2007, p. 242 - 252. 